\title{
LINHA DE FRENTE
}

Linha d'Água n.22 - a partir deste número, a revista conta com a participação professores de Universidades do exterior em sua Comissão Científica: Anton T. Brinckwirth (Virginia Commonwealth University), Dolores Vilavedra (Universidade de Santiago de Compostela) e Margarita Correia (Universidade de Lisboa).

Integra, também, a referida Comissão, o prof Eugênio Pagotti da Universidade Federal de Sergipe.

Passa a receber para publicação Artigos, Ensaios, Resenhas e Traduções.

Nesta edição, os Artigos apresentam questões voltadas aos processos discursivos em língua portuguesa, nas modalidades oral, escrita, virtual, em trabalhos com abordagem direcionada à pesquisa e ao ensino.

A Literatura Brasileira está contemplada por meio de artigo direcionado à oralidade na poética.

A Literatura Infantil destaca-se, neste número, por sua preocupação com concepções de infância.

O Ensaio reporta-se à atuação relevante de Carlos Franchi em meio aos estudos linguísticos.

A Resenha diz respeito a obra direcionada à mídia e à constituição de identidade.

São Paulo, julho de 2009.

Equipe Editorial 